\title{
EMOSI AKADEMIK, STRATEGI BELAJAR, DAN PRESTASI AKADEMIK SISWA SMA DI WILAYAH PERDESAAN
}

\author{
Mega Citrandini*), Neti Hernawati \\ Departemen IImu Keluarga dan Konsumen, Fakultas Ekologi Manusia, Institut Pertanian Bogor, Bogor 16680, \\ Indonesia
}

*)E-mail: megacitrandini24@gmail.com

\begin{abstract}
Abstrak
Prestasi akademik peserta didik merupakan salah satu indikator keberhasilan pelaksanaan pendidikan. Penelitian ini bertujuan untuk menganalisis karakteristik remaja, karakteristik keluarga, emosi akademik, dan strategi belajar serta pengaruhnya terhadap prestasi akademik siswa SMA. Pemilihan lokasi penelitan dilakukan secara purposive, yaitu di Kabupaten Bogor. Contoh pada penelitian ini merupakan siswa dari dua SMA yang berjumlah 132 orang yang dipilih secara proportional random sampling. Pengumpulan data dilakukan melalui penyebaran kuesioner yang diisi oleh contoh. Analisis data yang digunakan terdiri dari analisis deskriptif (nilai minimal, nilai maksimal, rata-rata, standar deviasi, dan frekuensi) dan analisis inferensia (uji korelasi Spearman, uji korelasi Pearson, dan uji regresi linear berganda). Hasil penelitian menemukan emosi positif-aktivasi menjadi emosi yang dominan dirasakan remaja. Strategi belajar yang paling sering digunakan adalah manajemen waktu/ lingkungan belajar dan mencari bantuan, sementara penggunaan strategi belajar secara umum masih rendah. Perempuan menunjukkan penggunaan strategi belajar dan capaian prestasi akademik yang lebih baik dibandingkan siswa laki-laki. Selanjutnya, emosi positif-aktivasi mampu meningkatkan penggunaan strategi belajar, dan penggunaan strategi belajar yang beragam akan meningkatkan capaian prestasi akademik remaja. Karakteristik keluarga ditemukan tidak berpengaruh signifikan, baik terhadap strategi belajar maupun prestasi akademik remaja.
\end{abstract}

Kata Kunci: emosi akademik, prestasi akademik, strategi belajar, remaja

\section{Academic Emotions, Learning Strategies, and Academic Achievement on High School Students in Rural Area}

\begin{abstract}
Students' academic achievement is one of main indicator of education goals. This research aimed to analyze adolescents' characteristics, family's characteristics, academic emotions, and learning strategies, and its effect on academic achievement of high school students. The locations were chosen purposively in Bogor District. Samples of this study were 132 high school students from both $X$ and $Y$ high schools by proportional random sampling technique. Data were collected through questionnaires and filled-in by samples. The data analysis used descriptive analysis (minimum value, maximum value, average, standard deviation, and frequency) and inferential analysis (Spearman correlation test, Pearson correlation test, and multiple linear regression test). Result showed that positive-activation emotion was mostly felt by adolescents. Learning strategies that mostly used were time/study environment management and help-seeking, meanwhile in general learning strategy usage was still low. Female students engaged more variative learning strategies and better academic achievement than male students. Positive-activation emotion had increased the learning strategies, and the variety of learning strategies usage will affect academic achievement positively. Meanwhile, family characteristics was found have no significant effect on learning neither strategies nor academic achievement.
\end{abstract}

Keywords: academic emotion, academic achievement, learning strategy, adolescent

\section{PENDAHULUAN}

Berdasarkan Undang-undang Nomor 20 Tahun 2003 tentang Sistem Pendidikan Nasional, pendidikan adalah usaha sadar dan terencana untuk mewujudkan suasana belajar dan proses pembelajaran agar peserta didik secara aktif mengembangkan potensi dirinya untuk memiliki kekuatan spiritual keagamaan, pengendalian diri, kepribadian, kecerdasan, akhlak mulia, serta keterampilan yang diperlukan dirinya, masyarakat, bangsa dan negara. Selanjutnya proses pembelajaran diartikan sebagai interaksi peserta didik dengan pendidik dan sumber belajar pada suatu lingkungan belajar. Adapun tujuan utama pembelajaran adalah memeroleh keahlian untuk menggunakan pengetahuan dan kemampuan yang diperoleh dalam berbagai situasi (OECD, 2010). Oleh 
karenanya, dengan tujuan pembelajaran tersebut diharapkan pembelajar mampu melakukan adaptasi secara fleksibel dan kreatif menggunakan ilmu-ilmu yang diperolehnya dari berbagai subjek pelajaran dalam kehidupannya.

Pelaku utama proses pembelajaran adalah pembelajar. Pembelajar dalam penelitian ini adalah remaja yang dalam sistem pendidikan disebut peserta didik atau siswa. Remaja merupakan fase dimana banyak terjadi perubahan fisik dan psikis. Secara biologis, otak manusia pada fase remaja masih terus tumbuh yang memengaruhi pengendalian perhatian dan perubahan aksi, kognisi, dan emosi yang kompleks serta mampu mengevaluasi perilaku yang berkaitan dengan tujuan tertentu (Court, 2013). Remaja sebagai siswa diharapkan mampu mencapai prestasi akademik yang baik. Namun, berbagai hasil penelitian menemukan terdapat berbagai faktor yang memengaruhi remaja dalam proses pembelajaran. Faktor yang diduga memengaruhi prestasi adalah strategi belajar remaja. Strategi belajar merupakan berbagai macam cara untuk mengingat, mengerti, dan memahami materi yang diajarkan. Strategi belajar digunakan oleh setiap orang untuk mencapai tujuannya (Zimmerman, 2000). Berbagai penelitian telah menemukan hasil yang konsisten bahwa penggunaan strategi belajar memengaruhi prestasi akademik (Barnard-Brak et al., 2010). Strategi belajar digunakan oleh remaja berdasarkan emosi yang dirasakannya terhadap proses dan kegiatan belajar yang diikutinya (Ahmed et al., 2013; Villavicencio \& Bernardo, 2012). Emosi yang dialami selama kegiatan pembelajaran disebut sebagai emosi akademik.

Emosi akademik adalah emosi-emosi yang muncul pada berbagai kondisi pembelajaran dan berhubungan langsung dengan proses kegiatan pencapaian prestasi maupun luaran capaian prestasi tersebut (Pekrun et al., 2011). Berdasarkan control-value theory, ketika individu merasa mampu atau tidak mampu mengontrol aktivitas dan luaran yang penting ataupun kurang penting menurut individu tersebut maka emosi akademik akan muncul (Pekrun et al., 2007). Faktor internal lain seperti usia dan jenis kelamin remaja (Bortoletto \& Boruchovitch, 2013; Bozpolat, 2016; Tinklin et al., 2001; Veas et al., 2016; dan Xiying, 2010), serta faktor eksternal seperti usia orang tua, pendidikan orang tua, pendapatan, dan besar keluarga juga diduga berpengaruh terhadap strategi belajar dan prestasi akademik remaja (Suksmadi et al.,
2009). Penelitian Villavicencio \& Bernardo (2012) mengenai emosi akademik positif, selfregulation, dan prestasi akademik menunjukkan bahwa emosi kegembiraan dan kebanggaan memoderatori hubungan selfregulation dengan nilai. Bagian dari selfregulation yang diteliti merupakan strategi belajar. Hal ini menunjukkan pentingnya peran emosi dan penggunaan strategi belajar selama kegiatan pembelajaran terhadap proses dan capaian akademik pada remaja (Pekrun et al., 2007; Pekrun et al., 2011; Villavicencio \& Bernardo, 2012).

Peraturan Kepala Badan Pusat Statistik Nomor 37 Tahun 2010 tentang Klasifikasi Perkotaan dan Perdesaan di Indonesia menyebutkan bahwa perdesaan adalah wilayah administrasi setingkat desa atau kelurahan yang belum memenuhi kriteria klasifikasi wilayah perkotaan seperti kepadatan penduduk dan keberadaan atau akses fasilitas perkotaan seperti sekolah, rumah sakit, dan hotel, dan presentase rumah tangga yang menggunakan listrik dan telepon. Beberapa ahli menyatakan bahwa ciri khas desa antara lain kehomogenan mata pencaharian penduduk, ikatan kekeluargaan yang erat, dan letaknya yang jauh dari pusat kota. Adanya perbedaan antara kota dan desa memungkinkan adanya kesenjangan baik kualitas maupun kuantitas fasilitas pendidikan yang dapat diakses oleh kedua wilayah, terutama keterbatasan wilayah desa untuk mengakses fasilitas yang terdapat di perkotaan. Bukti adanya kesenjangan akses perolehan pendidikan antara wilayah perkotaan dan wilayah perdesaan, yaitu penduduk wilayah perdesaan paling banyak tingkat pendidikan akhir pada sekolah dasar, sementara pada perkotaan adalah sekolah menengah atas. Perbedaan ini dapat berimbas pada proses pendidikan yang dilaksanakan, sehingga wilayah perdesaan yang dijadikan sebagai lokasi penelitian menjadi keunikan dari penelitian ini dengan harapan hasil penelitian ini dapat menjadi pertimbangan peningkatan usaha penyebaran pendidikan yang merata ke seluruh wilayah baik perdesaan maupun perkotaan.

Berdasarkan pemaparan sebelumnya maka tujuan penelitian ini adalah untuk: (1) mengetahui karakteristik emosi akademik, strategi belajar, dan prestasi akademik remaja di wilayah perdesaan; (2) menganalisis pengaruh karakteristik remaja, karakteristik keluarga, dan emosi akademik terhadap strategi belajar remaja di wilayah perdesaan; dan (3) menganalisis pengaruh karakteristik remaja, karakteristik keluarga, dan strategi 
belajar terhadap prestasi akademik remaja di wilayah perdesaan.

\section{METODE}

Desain penelitian yang digunakan adalah cross sectional study, yaitu penelitian yang dilakukan dengan meneliti pada satu waktu tertentu. Penelitian ini dilaksanakan di dua Sekolah Menengah Atas Negeri di Kabupaten Bogor. Penentuan lokasi penelitian dilakukan secara purposive dengan pertimbangan kedua sekolah tersebut berada di wilayah perdesaan dan jumlah siswa di sekolah terpilih merupakan sepuluh besar siswa terbanyak di sekolah negeri se-Kabupaten Bogor. Selain itu, pemilihan lokasi juga mempertimbangkan lokasi yang cukup dekat dengan kampus IPB Dramaga sehingga diharapkan hasil penelitian memiliki kebermanfaatan yang nyata bagi wilayah di sekitar kampus IPB. Pengambilan data penelitian ini dilaksanakan mulai dari Maret hingga Mei 2015.

Contoh pada penelitian ini adalah siswa kelas XI. Pertimbangan pemilihan tersebut adalah karena siswa kelas XI telah menyesuaikan diri lebih lama dengan lingkungan pendidikan di sekolahnya dibandingkan dengan siswa kelas $X$, sudah dibagi ke dalam dua program studi, dan belum disibukkan dengan persiapan Ujian Nasional seperti siswa kelas XII.

Cara pengambilan contoh yang digunakan adalah proportional random sampling yang dilakukan terhadap siswa kelas XI program studi IPA dan IPS dari setiap lokasi penelitian. Proses awal dari pengambilan contoh adalah penentuan dua SMA yang menjadi lokasi penelitian, kemudian jumlah siswa dari setiap kelas XI IPA dan IPS dari kedua SMA diambil dengan teknik proportional random sampling. Hasil dari teknik sampling tersebut diperoleh jumlah responden dari SMA X yaitu: (i) 45 siswa dari kelas XI IPA; dan (ii) 34 siswa dari kelas XI IPS. Sementara itu, dari SMA Y diperoleh: (i) 38 siswa dari kelas XI IPA; dan (ii) 33 siswa dari kelas XI IPS. Total siswa yang menjadi partsipan penelitian ini adalah berjumlah 150 siswa. Namun, jumlah responden yang hadir dan melengkapi data kuesioner adalah 132 dari 150 contoh yang telah ditetapkan sebelumnya. Oleh karenanya, proses analisis data hanya dilakukan untuk 132 siswa yang telah mengisi kuesioner secara lengkap.

Data yang dikumpulkan adalah data primer dan sekunder. Adapun data primer terdiri dari karakteristik remaja (usia, jenis kelamin, dan program studi), karakteristik keluarga (usia, lama pendidikan orang tua, besar keluarga, dan pendapatan), emosi akademik, dan strategi belajar. Pengisian kuesioner oleh responden (self-report) dilakukan setelah responden mendapatkan penjelasan dan setiap pertanyaan akan dipandu oleh peneliti untuk meminimalisir perbedaan persepsi pada setiap butir kuesioner.

Emosi akademik diukur menggunakan Achievement Emotions Questionnaire (AEQ) yang dikembangkan oleh Pekrun et al. (2005) yang dimodifikasi menjadi 80 butir pernyataan yang mengukur tiga kelompok emosi akademik (positif-aktivasi, negatif-aktivasi, dan negatifdeaktivasi). Instrumen tersebut memiliki nilai Cronbach's alpha 0,875. Sementara itu, strategi belajar diukur menggunakan Motivated Strategies for Learning Questionnaire (MSLQ) yang dikembangkan oleh Pintrich et al. (1991), dengan Cronbach's $\alpha$ 0,917. Dimensi dalam MSLQ yang digunakan pada penelitian ini adalah strategi belajar siswa, yang berjumlah 50 butir pernyataan. Seluruh butir pernyataan emosi akademik dan strategi belajar mempunyai skala jawaban berbentuk skala Likert dari 1=tidak pernah; 2 =jarang; 3 =sering; hingga $4=$ selalu.

Data primer diperoleh melalui teknik self-report dengan alat bantu kuesioner. Prosedur pertama yang dilakukan untuk mengambil data, yaitu peneliti memperkenalkan diri, memberi tahu judul dan tujuan dari penelitian, dan menjelaskan cara pengisian kuesioner. Kedua, peneliti mempersilahkan kepada responden untuk mengisi kuesioner. Ketiga, peneliti memastikan responden untuk bertanya langsung kepada peneliti ketika ada pertanyaan yang tidak dimengerti oleh responden. Peneliti memandu setiap pertanyaan agar meminimalisir perbedaan persepsi pada setiap butir kuesioner. Sementara itu, data sekunder dalam penelitian ini adalah data prestasi akademik. Data tersebut diperoleh melalui rapor responden dari pihak sekolah.

Data yang diperoleh diolah dan dianalisis secara deskriptif dan inferensia. Proses pengolahan data meliputi editing, coding, entering, scoring, dan cleaning data. Data karakteristik contoh terdiri dari usia, jenis kelamin, dan jurusan bidang studi. Data jenis kelamin dibedakan menjadi laki-laki dan perempuan. Data usia dibagi berdasarkan sebaran responden. Data jurusan bidang studi berdasarkan jurusan yang ada di sekolah yaitu IPA dan IPS. 
Selanjutnya, sistem scoring dibuat konsisten untuk variabel emosi akademik dan strategi belajar. Penentuannya didasarkan pada jawaban dari setiap pernyataan yang ada di kuesioner yang kemudian masing-masing dimensi dijumlahkan dan dikategorikan menggunakan indeks. Indeks diperoleh dengan cara mengurangi skor responden dengan skor minimal, kemudian dibagi dengan hasil pengurangan dari skor maksimal dengan skor minimal, dan hasil pembagian tersebut kemudian dikalikan dengan 100.

Cara menentukan variabel emosi akademik yaitu memilih satu emosi yang memiliki skor paling tinggi pada setiap responden sebagai emosi yang paling dominan. Pengkategorian variabel strategi belajar menggunakan cut-off yang terdiri dari tiga kategori, yaitu rendah $(0,0-59,0)$; sedang $(60,0-80,0)$; dan tinggi $(81,0-100,0)$. Sementara itu, prestasi akademik dikategorikan berdasarkan Permendiknas Nomor 81a Tahun 2013 dengan pengkategorian, yaitu kurang $(0,00-2,49)$; cukup (2,50-2,99); baik $(3,00-3,49)$; dan sangat baik $(3,50-4,00)$.

Analisis deskriptif yang dilakukan adalah nilai minimal, nilai maksimal, rataan, standar deviasi, dan frekuensi. Analisis inferensia yang dilakukan adalah uji korelasi Spearman dan korelasi Pearson untuk mengetahui hubungan antarvariabel yang diteliti. Selain itu, uji regresi linear berganda dilakukan untuk melihat faktorfaktor yang memengaruhi strategi belajar dan prestasi akademik.

\section{HASIL}

\section{Karakteristik Remaja dan Keluarga}

Sebaran usia orang tua remaja dibagi berdasarkan pengelompokkan usia oleh Papalia \& Olds (1981). Hasil penelitian menunjukkan bahwa sebagian besar berada pada kategori usia dewasa madya (40-65 tahun) yaitu sebesar 80,3 persen ayah dan 53 persen ibu. Proporsi tertinggi kedua adalah kelompok usia dewasa muda (20-40 tahun) sebesar 16,7 persen ayah dan 46.2 persen ibu. Selain itu, diperoleh hasil bahwa terdapat ayah $(2,3 \%)$ dan ibu $(0,8 \%)$ remaja yang telah meninggal dunia. Berdasarkan lama pendidikan orang tua remaja, mayoritas lama pendidikan ayah $(60,6 \%)$ menyelesaikan pendidikan dasar (0-9 tahun). Sementara itu, pendidikan menengah (10-12 tahun) dan pendidikan tinggi ( $\geq 13$ tahun) diselesaikan oleh 27,3 persen dan 12,1 persen ayah. Sementara itu, untuk pendidikan ibu, lama pendidikan yang sudah diselesaikan relatif sama proporsinya dengan ayah, yaitu 65,9 persen untuk pendidikan dasar (0-9 tahun), 26,5 persen untuk pendidikan menengah (1012 tahun), dan 7,6 persen untuk pendidikan tinggi ( $\geq 13$ tahun).

Berdasarkan besar keluarga, mayoritas remaja $(47,7 \%)$ mempunyai keluarga sedang (5-6 orang) dan proporsi terkecil adalah keluarga besar ( $\geq 7$ orang) sebanyak 26,5 persen; dan sisanya adalah keluarga kecil (1-4 orang) sebanyak 25,8 persen. Berdasarkan pekerjaan, proporsi terbanyak pekerjaan ayah adalah wiraswasta $(31,1 \%)$ dan pekerjaan ibu adalah ibu rumah tangga (78\%). Selain wiraswasta, ayah dalam penelitian ini juga mempunyai profesi sebagai buruh (28\%), pedagang $(12,1 \%)$, dan PNS atau pegawai BUMN (10,6\%). Untuk pekerjaan ibu, proporsi terbesar adalah ibu rumah tangga, dan lainnya ada yang bekerja sebagai pedagang $(9,1 \%)$, wiraswasta $(6,1 \%)$, PNS atau pegawai BUMN $(3,8 \%)$, dan lainnya $(2,3 \%)$. Sementara itu, berdasarkan garis kemiskinan Jawa Barat Tahun 2015, analisis pendapatan keluarga menunjukkan bahwa lebih dari setengah keluarga remaja tergolong pada keluarga tidak miskin $(58,3 \%)$ dengan rata-rata pendapatan per kapita sebesar Rp547.000.

\section{Emosi Akademik}

Emosi akademik merupakan bagian dari kehidupan akademik yang jarang mendapatkan perhatian dibandingkan dengan kemampuan kognitif ataupun motivasi (Trigwell et al., 2012). Pada penelitian ini, terdapat tiga kategori emosi akademik yang diteliti, yaitu positif-aktivasi, negatif-aktivasi, dan negatifdeaktivasi. Hasil dari Tabel 1 memperlihatkan bahwa sebanyak 92,4 persen remaja memiliki emosi positif-aktivasi, dan emosi negatifaktivasi serta negatif-deaktivasi masingmasing sebanyak 3,8 persen.

Emosi akademik diukur pada berbagai kondisi, yaituketika, sebelum, dan sesudah kegiatan belajar di kelas, belajar mandiri, dan ujian. Hasil penelitian menunjukkan bahwa emosi positif-aktivasi menjadi emosi yang dominan pada seluruh kondisi pembelajaran

Tabel 1 Sebaran remaja berdasarkan emosi akademik

\begin{tabular}{lrr}
\hline Kategori & $\mathrm{n}$ & $\%$ \\
\hline Positif-aktivasi & 122 & 92,4 \\
Negatif-aktivasi & 5 & 3,8 \\
Negatif-deaktivasi & 5 & 3,8 \\
\hline Total & 132 & 100,0 \\
\hline
\end{tabular}


Emosi positif-aktivasi paling banyak dirasakan oleh remaja saat sebelum belajar di kelas dan ketika ujian. Saat sebelum belajar remaja menunjukkan rasa percaya diri dan harapan yang tinggi untuk bisa berhasil memahami materi memotivasi untuk berusaha lebih baik lagi. Sementara ketika ujian, remaja lebih cenderung bangga atas pengetahuan dan kemampuan dalam mengerjakan ujian serta harapan untuk sukses menjadi motivasi untuk melakukan usaha yang terbaik.

Emosi positif-aktivasi pada situasi akademik adalah munculnya kebahagiaan, rasa bangga, dan harapan terhadap mata pelajaran yang diterima. Emosi positif-aktivasi menjadi emosi yang dominan muncul pada seluruh kondisi pembelajaran yang diukur. Namun, ada lima butir pernyataan yang mendapat respon beragam, yaitu masih sedikit remaja yang menanti-nanti kegiatan belajar di kelas maupun belajar mandiri, rendahnya keinginan untuk berpartisipasi ketika belajar di kelas, dan keinginan untuk belajar lebih banyak dari yang diperlukan karena menikmati kegiatan tersebut juga masih rendah. Remaja yang menikmati ketika mengerjakan ujian juga masih terbilang sedikit dibandingkan dengan indikator emosi positif-aktivasi lainnya.

Kelima butir tersebut merupakan indikator emosi kebahagiaan. Sementara itu, dibandingkan dengan butir pernyataan terkait emosi positif-aktivasi lainnya yaitu rasa bangga dan harapan, kelima butir tersebut mendapat respon yang relatif rendah (tidak pernah hingga jarang dirasakan atau dialami). Hal ini dapat diartikan bahwa remaja masih jarang atau kesulitan menikmati kegiatan belajar, baik di kelas maupun belajar mandiri. Selain itu, rasa bangga terhadap persiapan menghadapi ujian pada kondisi sebelum ujian juga mendapatkan respon yang cenderung lebih rendah dibanding dengan butir pernyataan lainnya.

\section{Strategi Belajar}

Strategi belajar merupakan bagian dari pengaturan diri dalam belajar (self-regulated learning). Dalam penelitian ini, strategi belajar dikelompokkan menjadi rendah, sedang, dan tinggi. Strategi yang rendah berarti remaja menggunakan strategi belajar yang kurang variatif pada kegiatan pembelajarannya. Semakin tinggi skor strategi belajar yang diperoleh maka semakin sering dan variatif strategi belajar yang digunakan oleh remaja. Secara keseluruhan, sebagian besar remaja $(63,6 \%)$ menunjukkan penggunaan strategi belajar rendah, kemudian 34,4 persen mampu menggunakan strategi pada capaian sedang, dan sisanya 2,3 persen yang sudah mampu dan sering menggunakan berbagai macam strategi belajar (Tabel 2).

Berdasarkan dimensi strategi belajar, terdapat tujuh dimensi yang memiliki proporsi terbanyak (mulai dari $56,1 \%$ sampai $81,4 \%$ ) yang berada pada kategori rendah (Tabel 2). Ketujuh dimensi strategi belajar tersebut terdiri dari pengaturan usaha, belajar dengan teman sebaya, latihan, metakognisi pengaturan diri, elaborasi, organisasi, dan berpikir kritis. Strategi latihan, elaborasi, organisasi, dan berpikir kritis menunjukkan capaian yang dominan berkategori rendah yang masingmasing mempunyai proporsi 68,2 persen, 68,9 persen, 73,5 persen, dan 81,4 persen. Hasil temuan tersebut menunjukkan bahwa remaja masih jarang mengulang bacaan, mengingat kata kunci, mengambil dan menghubungkan informasi dari berbagai sumber, menandai dan meringkas, melakukan cross-check informasi yang didapat saat belajar, dan proses-proses kognisi serupa lainnya.

Strategi metakognisi pengaturan diri juga menunjukkan hasil proporsi terbesar pada kategori rendah juga $(68,2 \%)$. Contoh dari strategi metakognisi pengaturan diri, yaitu mengubah gaya belajar saat materi sulit dipahami, memahami bagian mana dari materi yang tidak mampu dipahaminya, dan menyadari saat dirinya kehilangan fokus saat belajar yang seharusnya dapat ditingkatkan penggunaannya saat proses pembelajaran.

Tabel 2 Sebaran remaja berdasarkan dimensi strategi belajar

\begin{tabular}{|c|c|c|c|c|c|c|}
\hline \multirow{2}{*}{$\begin{array}{l}\text { Dimensi } \\
\text { strategi } \\
\text { belajar }\end{array}$} & \multicolumn{2}{|c|}{ Rendah } & \multicolumn{2}{|c|}{ Sedang } & \multicolumn{2}{|c|}{ Tinggi } \\
\hline & $\mathrm{n}$ & $\%$ & $n$ & $\%$ & $\mathrm{n}$ & $\%$ \\
\hline Latihan & 90 & 68,2 & 24 & 18,2 & 18 & 13,6 \\
\hline Elaborasi & 91 & 68,9 & 35 & 26,5 & 6 & 4,5 \\
\hline Organisasi & 97 & 73,5 & 25 & 18,9 & 10 & 7,6 \\
\hline Berpikir kritis & 111 & 81,4 & 16 & 12,1 & 5 & 3,8 \\
\hline $\begin{array}{l}\text { Metakognisi } \\
\text { pengaturan } \\
\text { diri }\end{array}$ & 90 & 68,2 & 39 & 29,5 & 3 & 2,3 \\
\hline $\begin{array}{l}\text { Manajemen } \\
\text { waktu dan } \\
\text { lingkungan } \\
\text { belajar }\end{array}$ & 53 & 40,2 & 68 & 51,5 & 11 & 8,3 \\
\hline $\begin{array}{l}\text { Pengaturan } \\
\text { usaha } \\
\text { Belajar }\end{array}$ & 74 & 56,1 & 46 & 34,8 & 12 & 9,1 \\
\hline $\begin{array}{l}\text { dengan } \\
\text { teman } \\
\text { sebaya }\end{array}$ & 77 & 58,3 & 45 & 34,1 & 10 & 7,6 \\
\hline $\begin{array}{l}\text { Mencari } \\
\text { bantuan }\end{array}$ & 46 & 34,8 & 62 & 47,0 & 24 & 18,2 \\
\hline
\end{tabular}


Berbeda dengan strategi manajemen waktu dan lingkungan belajar, serta strategi mencari bantuan yang mayoritas berkategori sedang (51,5\% dan 47,0\%). Hal ini menunjukkan bahwa remaja sudah cukup baik dalam memanfaatkan waktu belajar, mengikuti jadwal belajar, memahami waktu dan tempat yang cocok bagi dirinya untuk belajar, mau dan mampu bertanya baik kepada guru maupun teman agar dapat memahami materi pelajaran, mengetahui keberadaan, dan memahami cara memanfaatkan lingkungan di sekitarnya agar dapat lebih memahami materi pelajaran yang disampaikan di sekolah.

Hasil penelitian menunjukkan bahwa strategi belajar dalam dimensi manajemen waktu dan lingkungan belajar yang paling banyak dilakukan, yaitu kehadiran pada setiap kegiatan di kelas, diikuti dengan membaca catatan dan materi pelajaran sebelum ujian. Pada dimensi mencari bantuan, strategi yang paling banyak dilakukan adalah bertanya kepada teman untuk memahami suatu materi dan mencari, serta menemukan teman yang bisa dimintai bantuan. Selain itu, bekerja sama dengan teman sekelas dalam menyelesaikan tugas yang diberikan juga menjadi strategi yang banyak dilakukan. Sementara itu, strategi yang paling jarang dilakukan adalah membuat chart, diagram, tabel sederhana, dan pertanyaan-pertanyaan untuk membantu memahami materi. Remaja juga masih jarang menghubungkan ide pokok antarmata pelajaran dan masih kesulitan untuk menyesuaikan dan mengubah gaya belajar ketika materi sulit dimengerti. Hal ini menunjukkan bahwa penggunaan strategi kognitif dan metakognitif remaja masih dapat ditingkatkan sehingga semakin beragam strategi yang dapat diterapkan oleh remaja pada berbagai mata pelajaran yang diikutinya.

\section{Prestasi Akademik}

Prestasi akademik merupakan hasil yang dicapai oleh siswa setelah melalui proses pembelajaran. Berdasarkan Peraturan Menteri Pendidikan Nasional Nomor 81a Tahun 2013, prestasi akademik dibagi ke dalam empat kategori yaitu kurang, cukup, baik, dan sangat baik. Hasil penelitian menunjukkan bahwa prestasi akademik remaja hanya tersebar pada dua kategori saja, yaitu prestasi yang baik sebanyak 92,4 persen dan sisanya $(7,6 \%)$ memiliki prestasi akademik yang cukup. Prestasi akademik remaja yang paling rendah sebesar 2,82 dan paling tinggi adalah 3,49 dengan rata-rata 3,2 . Hasil analisis prestasi akademik remaja tersaji pada Tabel 3.
Tabel 3 Sebaran remaja berdasarkan prestasi akademik

\begin{tabular}{lrr}
\hline Kategori & $\mathrm{n}$ & \multicolumn{2}{c}{$\%$} \\
\hline Kurang $(0,00-2,49)$ & 0 & 0,0 \\
Cukup $(2,50-2,99)$ & 10 & 7,6 \\
Baik $(3,00-3,49)$ & 122 & 92,4 \\
Sangat baik $(3,50-4,00)$ & 0 & 0,0 \\
\hline Total & 132 & 100 \\
Min-Maks & $2,82-3,49$ \\
Rataan $\pm S D$ & $3,2 \pm 0,15$ \\
\hline
\end{tabular}

\section{Pengaruh Karakteristik Remaja, Karakteristik Keluarga, dan Emosi Akademik terhadap Strategi Belajar}

Model pertama dalam penelitian ini adalah menjadikan variabel strategi belajar remaja sebagai variabel terikat dan hasil uji regresi menunjukkan nilai adjusted $R^{2}$ sebesar 0,645 yang berarti variabel bebas dalam penelitian ini yaitu karakteristik remaja, karakteristik keluarga, dan emosi akademik memengaruhi strategi belajar sebesar 64,5 persen. Sementara itu, sebanyak 35,5 persen dipengaruhi oleh faktor lain yang tidak diteliti pada penelitian ini.

Tabel 4 Hasil uji regresi variabel bebas yang memengaruhi strategi belajar remaja di wilayah perdesaan

\begin{tabular}{|c|c|c|c|}
\hline \multirow{2}{*}{ Variabel } & \multicolumn{3}{|c|}{ Strategi Belajar } \\
\hline & B & $\beta$ & Sig \\
\hline Konstanta & 36,565 & & 0,035 \\
\hline $\begin{array}{l}\text { Usia remaja } \\
\text { (tahun) }\end{array}$ & $-1,395$ & $-0,082$ & 0,157 \\
\hline $\begin{array}{l}\text { Jenis kelamin } \\
\text { remaja ( } 0=\text { laki- } \\
\text { laki, } \\
1=\text { perempuan })\end{array}$ & 3,479 & 0,148 & 0,015 \\
\hline Usia ayah (tahun) & 0,007 & 0,004 & 0,962 \\
\hline Usia ibu (tahun) & $-0,018$ & $-0,011$ & 0,912 \\
\hline $\begin{array}{l}\text { Lama pendidikan } \\
\text { ayah (tahun) }\end{array}$ & 0,060 & 0,019 & 0,809 \\
\hline $\begin{array}{l}\text { Lama pendidikan } \\
\text { ibu (tahun) }\end{array}$ & 0,081 & 0,025 & 0,732 \\
\hline $\begin{array}{l}\text { Besar keluarga } \\
\text { (orang) }\end{array}$ & 0,112 & 0,018 & 0,791 \\
\hline $\begin{array}{l}\text { Pendapatan per } \\
\text { kapita (rupiah/ } \\
\text { bulan) }\end{array}$ & $2,3 \times 10^{-2}$ & 0,098 & 0,161 \\
\hline $\begin{array}{l}\text { Emosi akademik } \\
\text { positif-aktivasi }\end{array}$ & 0,628 & 0,778 & $0,000^{*}$ \\
\hline $\begin{array}{l}\text { Emosi akademik } \\
\text { negatif-aktivasi }\end{array}$ & $-0,004$ & $-0,004$ & 0,961 \\
\hline $\begin{array}{l}\text { Emosi akademik } \\
\text { negatif-deaktivasi }\end{array}$ & $-0,018$ & $-0,021$ & 0,836 \\
\hline $\mathrm{R}^{2}$ & & 0,676 & \\
\hline Adjusted $\mathrm{R}^{2}$ & & 0,645 & \\
\hline $\mathrm{F}$ & & 22,022 & \\
\hline Sig & & $0,000^{* *}$ & \\
\hline
\end{tabular}

Keterangan: "signifikan pada $p$-value $<0,05$; "* signifikan pada $p$-value $<0,01$ 
Tabel 4 menunjukkan variabel-variabel yang berpengaruh paling nyata terhadap strategi belajar adalah jenis kelamin dan emosi akademik positif-aktivasi. Jenis kelamin remaja menunjukkan pengaruh yang signifikan $(\mathrm{B}=3,479, \quad \mathrm{p}=0,015)$, artinya perempuan menunjukkan penggunaan strategi belajar yang lebih baik dibanding laki-laki. Selanjutnya adalah variabel emosi positif-aktivasi menunjukkan pengaruh signifikan $(B=0,628$, $\mathrm{p}=0,000)$ terhadap strategi belajar yang berarti meningkatnya 1 poin emosi positif-aktivasi yang dirasakan remaja akan meningkatkan 0,628 poin penggunaan strategi belajar.

\section{Pengaruh Karakteristik Remaja, Karakteristik Keluarga, dan Strategi Belajar terhadap Prestasi Akademik}

Hasil uji regresi pada model kedua dengan variabel terikat adalah strategi belajar menunjukkan bahwa adjusted $R^{2}$ sebesar 0,233 yang berarti variabel yang diteliti yaitu karakteristik remaja (usia remaja, jenis kelamin), karakteristik keluarga (usia ayah dan ibu, lama pendidikan ayah dan ibu, besar keluarga, dan pendapatan keluarga), dan strategi belajar memengaruhi prestasi akademik sebesar 23,3 persen. Sementara itu, sebanyak 76,7 persen dipengaruhi oleh variabel bebas yang tidak diteliti dalam penelitian ini.

Tabel 5 Hasil uji regresi faktor-faktor yang memengaruhi prestasi akademik remaja di wilayah perdesaan

\begin{tabular}{|c|c|c|c|}
\hline \multirow{2}{*}{ Variabel } & \multicolumn{3}{|c|}{ Prestasi Akademik } \\
\hline & B & $\beta$ & Sig \\
\hline Konstanta & 2,540 & & 0,000 \\
\hline $\begin{array}{l}\text { Usia remaja } \\
\text { (tahun) }\end{array}$ & 0,028 & 0,125 & 0,141 \\
\hline $\begin{array}{l}\text { Jenis kelamin } \\
\text { remaja } \\
\text { (0=laki-laki, } \\
1=\text { perempuan) }\end{array}$ & 0,077 & 0,251 & $0,004^{*}$ \\
\hline $\begin{array}{l}\text { Usia ayah } \\
\text { (tahun) }\end{array}$ & $-0,002$ & $-0,084$ & 0,542 \\
\hline Usia ibu (tahun) & $-0,001$ & $-0,048$ & 0,732 \\
\hline $\begin{array}{l}\text { Lama pendidikan } \\
\text { ayah (tahun) }\end{array}$ & 0,003 & 0,076 & 0,516 \\
\hline $\begin{array}{l}\text { Lama pendidikan } \\
\text { ibu (tahun) }\end{array}$ & $-0,002$ & $-0,059$ & 0,580 \\
\hline $\begin{array}{l}\text { Besar keluarga } \\
\text { (oang) }\end{array}$ & 0,010 & 0,127 & 0,199 \\
\hline $\begin{array}{l}\text { Pendapatan per } \\
\text { kapita (rupiah/ } \\
\text { bulan) }\end{array}$ & $-5,2 \times 10^{-5}$ & $-0,172$ & 0,090 \\
\hline Strategi belajar & 0,004 & 0,332 & 0,000 * \\
\hline $\mathrm{R}^{2}$ & & 0,287 & \\
\hline Adjusted $\mathrm{R}^{2}$ & & 0,233 & \\
\hline $\mathrm{F}$ & & 5,283 & \\
\hline Sig & & $0,000^{* *}$ & \\
\hline
\end{tabular}

Tabel 5 menunjukkan jenis kelamin berpengaruh signifikan ( $B=0,077, \quad p=0,004)$ terhadap prestasi akademik. Hasil ini dapat diartikan bahwa perempuan memeroleh capaian prestasi akademik yang lebih baik dibandingkan remaja laki-laki. Selain itu, strategi belajar juga berpengaruh signifikan terhadap capaian prestasi akademik. Strategi belajar berpengaruh positif signifikan $(B=0,004, \quad p=0,000)$ terhadap prestasi akademik. Hal ini berarti meningkatnya satu poin penggunaan strategi belajar akan meningkatkan 0,004 poin capaian prestasi akademik. Sementara itu, variabel usia remaja, usia ayah dan ibu, lama pendidikan ayah dan ibu, besar keluarga serta pendapatan per kapita tidak berpengaruh signifikan terhadap prestasi akademik.

\section{PEMBAHASAN}

Perkembangan remaja dapat dilihat dari berbagai dimensi, salah satu yang dianggap paling penting adalah perkembangan kognitif yang dapat diukur diantaranya melalui prestasi akademik remaja di sekolah. Berbagai faktor memengaruhi kemampuan remaja dalam menjalani berbagai aktivitas terkait pembelajaran seperti kegiatan belajar di kelas, belajar mandiri, dan evaluasi atau ujian. Penelitian ini menguji dua model penelitian. Model pertama yaitu menganalisis pengaruh variabel bebas karakteristik remaja, karakteristik keluarga, dan emosi akademik terhadap penggunaan strategi belajar remaja; dan model kedua adalah menganalisis pengaruh variabel bebas karakteristik remaja, karakteristik keluarga, dan strategi belajar terhadap prestasi akademik remaja.

Penelitian ini tidak menemukan pengaruh yang signifikan dari variabel-variabel karakteristik remaja dan keluarga terhadap strategi belajar, kecuali variabel jenis kelamin remaja. Hal ini dapat diakibatkan oleh beberapa kemungkinan. Usia remaja tidak berpengaruh signifikan dapat dikarenakan rentang usia yang sempit dan sebaran yang cenderung mengumpul pada satu kategori usia sehingga perkembangan kemampuan kognitif yang memengaruhi strategi belajar berada pada tahap capaian kemampuan yang relatif setara. Selain itu, usia dan lama pendidikan orang tua juga tidak menunjukkan pengaruh yang signifikan terhadap strategi belajar maupun prestasi akademik. Menurut Veas et al., (2016), pengaruh lama pendidikan orang tua dan status ekonomi keluarga dalam memengaruhi prestasi akademik memiliki variabel antara yaitu keterlibatan orang tua 
dalam kegiatan belajar anak. Keterlibatan yang dimaksud, seperti memberi dukungan dan waktu ketika anak mengerjakan pekerjaan rumah, harapan orang tua terhadap capaian akademik, serta ketertarikan orang tua dalam proses dan kegiatan pendidikan anak. Variabel antara yang tidak diteliti ini mungkin mampu menjelaskan penyebab karakteristik keluarga yang dibahas dalam penelitian ini tidak berpengaruh signifikan. Selain itu, pada tahapan perkembangannya, remaja cenderung lebih banyak berinteraksi dengan lingkungan sosial pertemanan dibanding keluarga. Sekolah merupakan tempat proses pembelajaran sekaligus lingkungan remaja untuk bersosialisasi dengan teman sebaya sehingga pengaruh dari teman sebaya terhadap emosi yang dirasakan saat belajar dan strategi-strategi belajar, seperti belajar bersama dan berdiskusi, dianggap lebih berperan dibandingkan dengan pengaruh dari orang tua maupun keluarga.

Hasil uji regresi juga menunjukkan bahwa perempuan melakukan penggunaan strategi yang lebih baik dibandingkan dengan laki-laki. Hal ini didukung dengan tabulasi silang antara jenis kelamin dan strategi belajar yang menunjukkan bahwa seluruh remaja yang berada pada kategori strategi belajar yang tinggi merupakan remaja perempuan. Selain itu, pada kategori strategi belajar sedang lebih dari tiga perempat merupakan remaja perempuan. Hasil ini sejalan dengan penelitian sebelumnya yang menemukan bahwa jenis kelamin merupakan salah satu faktor yang berpengaruh signifikan terhadap penggunaan strategi belajar, yaitu perempuan yang menunjukkan penggunaan strategi belajar yang lebih variatif dibandingkan laki-laki (Bozpolat, 2016; Xiying, 2010).

Variabel lain yang berpengaruh terhadap strategi belajar adalah emosi akademik positifaktivasi. Hasil yang ditemukan menunjukkan semakin remaja merasakan emosi positifaktivasi yaitu kebahagiaan, harapan, dan rasa bangga pada kegiatan pembelajaran maka strategi belajar yang digunakan pun semakin banyak dan beragam. Hasil tersebut sejalan dengan penelitian terdahulu yang membuktikan hal serupa (Ahmed et al., 2013; Villavicencio \& Bernardo, 2012). Berdasarkan hal ini maka dapat disimpulkan bahwa penelitian ini sejalan dengan teori dan mendukung penelitian terdahulu yang menemukan jenis kelamin dan emosi positifaktivasi merupakan variabel yang memengaruhi penggunaan strategi belajar secara signifikan.
Peran emosi akademik dalam penelitian ini membuktikan teori control-value (Pekrun, 2007) yang menjelaskan bahwa emosi memengaruhi strategi belajar yang kemudian berpengaruh terhadap prestasi akademik. Penelitian terdahulu menemukan bahwa emosi positif-aktivasi berpengaruh positif terhadap strategi belajar, emosi negatif-deaktivasi berpengaruh negatif, sementara emosi negatifaktivasi menunjukkan pengaruh yang masih ambivalen (Pekrun et al., 2002; Pekrun et al., 2011). Penelitian ini menemukan hasil yang konsisten pada emosi positif-aktivasi dan negatif-deaktivasi, meskipun hasil yang signifikan hanya pada emosi positif-aktivasi saja; sementara emosi negatif-aktivasi pada penelitian ini menunjukkan pengaruh yang tidak signifikan.

Emosi positif-aktivasi merupakan emosi yang muncul karena aktivitas yang dilakukan dianggap penting oleh remaja dan dirasa mampu untuk dikerjakan dan dipahami. Kondisi ini menyebabkan remaja merasa lebih tertantang dan termotivasi untuk memahami dan menyelesaikan materi dan tugas yang diberikan. Hal ini lah yang menyebabkan munculnya penggunaan strategi-strategi belajar pada remaja. Semakin tinggi tingkat kepentingan dan penilaian kemampuan dalam menyelesaikan tugas, maka strategi belajar yang digunakan untuk memahami dan menyelesaikan tugas juga akan semakin baik.

Sementara itu, pada model yang kedua, hasil uji regresi menunjukkan bahwa perempuan secara signifikan memeroleh capaian prestasi akademik yang lebih tinggi dibandingkan dengan laki-laki. Hasil tersebut sejalan dengan Veas et al., (2016) yang menemukan bahwa remaja perempuan menunjukkan prestasi yang lebih baik dibanding laki-laki. Penelitian lain yang memiliki keragaan wilayah maupun usia contoh yang serupa juga menemukan hasil bahwa perempuan menunjukkan prestasi yang lebih baik dibanding laki-laki (Theresya, 2013; Putri, 2013; Novita \& Latifah, 2014; \& Susandari, 2014). Hasil penelitian ini mendukung hipotesis penelitian jenis kelamin dan strategi belajar memengaruhi secara positif terhadap prestasi akademik.

Hasil uji pengaruh menunjukkan bahwa peningkatan strategi belajar yang digunakan berpengaruh nyata terhadap peningkatan prestasi akademik remaja. Hasil penelitian ini sejalan dengan penelitian Valle et al., (2008) yang menunjukkan tingginya penggunaan strategi belajar memengaruhi tingginya pula pretasi akademik, sementara strategi belajar 
yang rendah juga menyebabkan rendahnya prestasi pelajar. Hasil penelitian terdahulu yang juga sejalan adalah penelitian Situmorang \& Latifah (2014), Novianti (2014), Novita \& Latifah (2014) yang menemukan bahwa penggunaan strategi belajar yang baik dapat meningkatkan prestasi akademik remaja. Penelitian lain yang menunjukkan hasil serupa adalah penelitian Kosnin (2007) yang menemukan bahwa strategi belajar berpengaruh positif signifikan pada IPK baik pada siswa high-achiever maupun lowachiever. Selain itu, McClintic-Gilbert et al., (2013) juga menemukan pengaruh strategi belajar terhadap prestasi yaitu penggunaan strategi belajar yang hanya sekedar ingin menyelesaikan tugas atau strategi yang rendah menyebabkan rendahnya IPK yang diperoleh.

Strategi pengaturan diri dalam belajar berdasarkan pandangan sosial-kognitif merupakan salah satu komponen selfregulation yang ditemukan memiliki pengaruh terhadap prestasi akademik (Zimmerman \& Kitsantas, 2014). Hasil penelitian ini juga mendukung teori dan penelitian-penelitian terdahulu yang menemukan penggunaan strategi belajar yang baik memengaruhi secara positif prestasi akademik remaja. Remaja yang mampu melakukan regulasi diri dalam belajar memiliki tujuan akademik (academic goals), salah satunya adalah capaian prestasi yang baik. Dalam mencapai tujuan tersebut, remaja mampu melakukan beragam strategi belajar demi memeroleh pengetahuan dan kemampuan yang dibutuhkan tanpa bergantung pada orang lain seperti guru atau orang tua. Penggunaan strategi juga bergantung pada feedback kegiatan pendidikan. Jika suatu tugas tidak dapat dikuasai dan diselesaikan menggunakan suatu strategi maka remaja mampu menilai dan mengubah strategi yang digunakan hingga tujuan akademik tersebut tercapai. Remaja mempelajari strategi-strategi belajar berdasarkan stimulus yang diberikan dari lingkungan (penjelasan guru, soal, dan tugas yang diberikan atau melihat gaya belajar orang lain). Remaja yang mampu menyesuaikan strategi belajar yang digunakan untuk berbagai situasi dan kegiatan akademik akan mencapai prestasi akademik yang baik, sebagaimana tujuan yang telah ditetapkannya.

Hasil dari penelitian ini juga menunjukkan bahwa emosi positif memengaruhi penggunaan strategi belajar, kemudian strategi belajar memengaruhi prestasi akademik secara positif. Namun berdasarkan sebaran data, meskipun emosi positif-aktivasi menjadi emosi yang dominan dirasakan selama kegiatan pembelajaran, strategi belajar yang dilakukan oleh remaja cenderung rendah. Sementara itu, hasil akhir yang ditunjukkan dengan prestasi akademik menunjukkan hasil yang baik. Hal ini jika dikaitkan dengan strategi belajar remaja yang cenderung menggunakan strategi manajemen sumberdaya belajar, remaja cenderung lebih memanfaatkan lingkungannya dibandingkan menggunakan kemampuannya dalam mengolah informasi dan metakognisi. Hal ini dapat diakibatkan oleh kurangnya ketertarikan remaja terhadap kegiatan belajar sehingga tidak menimbulkan berbagai macam strategi belajar kognitif dan metakognitif yang diharapkan.

Oleh karenanya, untuk penelitian lanjutan, variabel-variabel lain yang tidak diteliti seperti motivasi, kecerdasan kognitif, prior knowledge, dan self-efficacy perlu dikaji lebih mendalam. Kajian lanjutan tersbeut akan mampu menjelaskan lebih komprehensif terkait fenomena strategi belajar yang rendah namun prestasi akademik yang diraih baik.

\section{SIMPULAN DAN SARAN}

Hasil penelitian menemukan emosi dominan yang ditunjukkan oleh responden adalah emosi positif-aktivasi. Emosi positif-aktivasi ditunjukkan responden pada seluruh kondisi pembelajaran, yaitu ketika, sebelum, dan sesudah kegiatan belajar di kelas, belajar mandiri, dan ujian. Penggunaan strategi belajar yang dilakukan oleh responden berada pada kategori rendah. Selain itu, responden lebih banyak menggunakan strategi mencari bantuan, serta manajemen waktu dan lingkungan belajar dibandingkan dengan strategi kognitif seperti latihan, elaborasi, organisasi, dan berpikir kritis. Sementara itu, strategi metakognisi pengaturan diri merupakan strategi yang paling jarang dilakukan. Temuan penelitian menunjukkan bahwa prestasi akademik yang dicapai oleh responden dengan proporsi terbanyak berada pada kategori baik.

Hasil uji regresi menunjukkan bahwa variabel bebas yang mempengaruhi strategi belajar secara signifikan dan positif pada penelitian ini yaitu jenis kelamin dan emosi positif-aktivasi. Variabel lainnya, yaitu karakteristik keluarga, karakteristik remaja (usia remaja), dan kedua kategori emosi tidak berpengaruh signifikan terhadap strategi belajar. Selanjutnya, uji regresi terhadap prestasi akademik ditemukan bahwa strategi belajar dan jenis kelamin 
berpengaruh signifikan dan positif terhadap prestasi akademik.

Berdasarkan hasil penelitian maka saran bagi pihak sekolah, yaitu memahami pentingnya emosi yang dirasakan siswa sebelum, ketika, dan setelah mengikuti kegiatan akademik seperti belajar di kelas, belajar mandiri, dan ujian. Selain itu, disarankan agar pihak sekolah mampu memfasilitasi dan menciptakan kondisi pembelajaran yang nyaman dan dapat dinikmati oleh siswa. Fasilitas maupun kondisi yang dimaksud seperti memberikan waktu selingan saat siswa mulai mengantuk, sarana pembelajaran yang lebih beragam yang dapat membantu siswa memahami materi, ataupun mengadakan diskusi-diskusi terkait isu yang sedang terjadi yang dapat dikaitkan dengan materi pembelajaran. Kondisi ini diharapkan dapat memunculkan emosi yang semakin positif sehingga kegiatan pembelajaran menjadi suatu hal yang dinikmati oleh remaja, bukan hanya sekedar menjalankan kewajiban bersekolah dan mendapatkan nilai yang baik. Proses pembelajaran juga dapat dibuat lebih beragam, dinamis, dan tidak monoton sehingga remaja diberi kesempatan untuk mengembangkan strategi belajar kognitif dan metakognitif lebih baik lagi, sebagaimana ditemukan pada penelitian ini strategi tersebut masih dapat ditingkatkan lagi.

Penelitian selanjutnya disarankan untuk meneliti variabel antara lainnya seperti motivasi, self-efficacy, dan goal orientation untuk semakin memahami pengaruh emosi akademik dan strategi belajar terhadap prestasi akademik. Saran lainnya adalah penggunaan sumber data lain selain nilai rapor siswa untuk menentukan kemampuan kognitif remaja.

\section{DAFTAR PUSTAKA}

Ahmed, W., Van der, Werf, G., Minnaert, A., Kuyper, H. (2013). Emotions, selfregulated learning, and achievement in mathematics: a growth curve analysis. Journal of Educational Psychology, 105, 150-161. doi:10.1037/a0030160.

Barnard-Brak, L., Paton, V. O., Lan, W. Y. (2010). Self-regulation across time of first-generation online learners. Research in Learning Technology, 18, 61-70.

doi:10.1080/09687761003657572.

Bortoletto, D., Boruchovitch, E. (2013). Learning strategies and emotional regulation of pedagogy students. Paidéia, 23, 235-242. doi:10.1590/198243272355201311.

Bozpolat, E. (2016). Investigation of the selfregulated learning strategies of student from the faculty of education using ordinal logistic regression analysis. Educational Sciences: Theory \& Practice, 16, 301-318. doi:10.12738/estp.2016.1.0281

Court, J. M. (2013). Immature brain in adolescence. Journal of Paediatrics and Child Health, 49, 883-886. doi:10.1111/jpc.12241.

Kosnin, A. M. (2007). Self-regulated learning and academic achievement in Malaysian undergraduates. International Education Journal, 8, 221-228.

McClintic-Gilbert, M. S., Corpus, J. H., Wormington, S. V., Haimovitz, K. (2013). The relationship among middle school students' motivational orientations, learning strategies, and academic achievement. Middle Grades Research Journal, 8, 1-12.

Novianti, N. (2014). Pengaruh gaya pengasuhan, motivasi, dan strategi pengaturan diri dalam belajar terhadap prestasi akademik remaja (Skripsi). Institut Pertanian Bogor, Bogor, Indonesia.

Novita, L., Latifah, M. (2014). Strategi pengaturan diri dalam belajar sebagai mediator harapan orang tua dan motivasi intrinsik terhadap prestasi akademik. Jurnal IImu Keluarga dan Konsumen, 7, 143-153.

[OECD] Organization for Economic Cooperation and Development. 2013. Structural policy country notes: Indonesia. Southeast Asian Economy Outlook 2013. Paris (FR): OECD.

Papalia, D. E., Olds, S. W. (1981). Human Development. New York, NY: McGrawhill Book Company. 2nd ed.

Pekrun, R., Goetz, T., Titz, W., Perry, R. P. (2002). Academic emotions in students' self-regulated learning and achievement: a program of qualitative and quantitative research. Educational Psychologist, 37, 91-105.

Pekrun, R., Goetz, T., Perry, R. P. (2005). Achievement Emotions Questionnaire User's Manual. University of Munich, Munich, DEU. 
Pekrun, R., Frenzel, A. C., Goetz, T., \& Perry, R. P. (2007). The control-value theory of achievement emotions: an integrative approach to emotions in education. Emotion in Education, 2007, 13-36.

Pekrun, R., Goetz, T., Frenzel, A. C., Barchfeld, P., \& Perry, R. P. (2011). Measuring emotions in students' learning and performance: the achievement emotions questionnaire (AEQ). Contemporary Educational Psychology, 36, 36-48.

Pintrich, P. R., Smith, D. A., Gracia, T., \& McKeachie, W. J. (1991). A manual for the use of Motivational Strategies for Learning Questionnaire (MSLQ). University of Michigan, Michigan, USA.

Putri, D. J. (2013). Analisis gender terhadap self-efficacy, self-regulated learning, dan prestasi akademik remaja dalam pelajaran Matematika dan Bahasa Indonesia (Skripsi). Institut Pertanian Bogor, Bogor, Indonesia.

Situmorang, Z. R. D., Latifah, M. (2014). Pengaruh dukungan sosial, konsep diri, dan strategi pengaturan diri dalam belajar terhadap prestasi akademik siswa SMP. Jurnal IImu Keluarga dan Konsumen, 7, 154-163.

Suksmadi, I., Sumarwan, U., Khomsan, A., Hartoyo. (2009). Kualitas remaja di Kabupaten Banyumas. Jurnal IImu Keluarga dan Konsumen, 2, 154-163.

Susandari, T. (2014). Pengaruh pengasuhan, self-efficacy, dan kecemasan terhadap prestasi akademik siswa SMP (Skripsi). Institut Pertanian Bogor, Bogor, Indonesia.

Theresya, J. (2013). Pengaruh gaya pengasuhan, self-efficacy, dan selfregulated learning terhadap prestasi akademik remaja (Skripsi). Institut Pertanian Bogor, Bogor, Indonesia.

Tinklin, T., Croxford, L., Frame, B., Ducklin, A. (2001). Gender and pupil performance in
Scotland's Schools (Paper work). University of Edinburgh, Edinburgh, GB.

Trigwell, K., Ellis, R. A., Han, F. (2012). Relations between students' approaches to learning, experienced emotions and outcomes of learning. Studies in Higher Education, $\quad 37, \quad 811-824$. doi:10.1080/03075079.2010.549220.

Valle, A., Núñez, J. C., Cabanach, R. G., González-Pienda, J. A., Rodríguez, S., \& Rosário, P. (2008). Self-regulated profiles and academic achievement. Psicothema, 20, 724-732.

Veas, A., Gilar, R., Miñano, P. (2016). The influence of gender, intellectual ability, academic self-concept, self-regulation, learning strategies, popularity, and parent involvement in early adolescence. International Journal of Information and Education Technology, 6, 591-597. doi:10.7763/IJIET.2016.V6.757.

Villavicencio, F. T., Bernardo, A. B. I. (2012). Positive academic emotions moderate the relationship between self-regulation and academic achievement. British Journal of Educational Psychology, 83, 329-340. doi:10.1111/j.20448279.2012.02064.x.

Xiying, F. (2010). A study of gender differences in English learning strategies of middle school students. Scientific Research, 18, 1-5.

Zimmerman, B. J. (2000). Attaining self regulation: $A$ social cognitive perspective. Handbook of Self Regulation. San Diego, CA: Academic Press.

Zimmerman, B. J., Kitsantas, A. (2014). Comparing students' self-discipline and self-regulation measures and their prediction of academic achievement. Contemporary Educational Psychology, 39 , 145-155. doi:j.cedpsych.2014.03.004. 